\title{
GENETIC VARIATION AND RELATIONS IN DIFFERENT GOAT POPULATIONS OF BANGLADESH
}

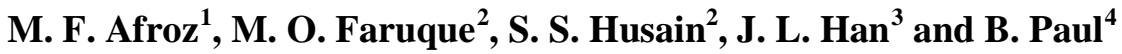

\begin{abstract}
The genetic relation among different populations and breeds of goats in Bangladesh was studied using 15 microsatellite markers. A total of 181 goat samples- 36 from Black Bengal of western part (BBW), 39 from Black Bengal of central part (BBC), 40 from Black Bengal of Hilly region (BBH), 28 from exotic breeds (JAM) and 39 from crossbred (CRW) were genotyped. The allele number per locus ranged from 2 to 12 . The average number of alleles per population was $5.69 \pm 2.32$, $5.38 \pm 2.02$, $5.23 \pm 2.28$, $6.08 \pm 2.33$, and $5.77 \pm 2.35$ for BBW, BBC, BBH, CRW and JAM, respectively. Heterozygosity was found in the range from $0.5049 \pm 0.0222$ (BBC) to $0.5751 \pm 0.0262$ (JAM). The genetic distance $\left(\mathrm{D}_{\mathrm{A}}\right)$ between $\mathrm{BBC}$ and JAM was the highest $(0.0627)$ and that between JAM and CRW was the lowest (0.0037). In the phylogenetic dendrogram, $\mathrm{BBC}$ and $\mathrm{BBH}$ grouped in the same cluster, while CRW and JAM formed another cluster. BBW formed a third cluster between those two clusters. The closest genetic relation between $\mathrm{BBW}$ and $\mathrm{CRW}$ indicates the introgression of exotic genes occurred more in BBW than BBC and BBH.
\end{abstract}

Key words: Bangladeshi goats, Microsatellite markers, Genetic variation, Dendrogram

\section{Introduction}

The goat is a very important and promising animal genetic resource in the developing countries, especially in Asia and Africa region. Of the total goat population, 92.76\% of goats are found in Asia and Africa. China, India, Pakistan and Bangladesh possess 35.36, 25.46, 10.79 and $7.05 \%$ of the total goat of Asia, respectively (FAOSTAT, 2009). Bangladesh has the $4^{\text {th }}$ highest population of goat in Asia. Bangladesh possesses 20.75 million goats at present (DLS, 2007). This species was neglected in the past. In the recent years, farmers and government are showing interest to utilize this species to increase the supply of meat and to alleviate poverty through creation of employment. Attention is being paid for their genetic improvement.

* Corresponding author: M. O. Faruque; E-mail: faruque_mdomar@yahoo.com

${ }^{1}$ Biotechnology Division, Bangladesh Livestock Research Institute, Savar, Bangladesh

${ }^{2}$ Department of Animal Breeding and Genetics, Bangladesh Agricultural University, Mymensingh-2202,

Bangladesh

${ }^{3}$ CAAS-ILRI Joint Laboratory on Livestock and Forage Genetic Resources, Institute of Animal Science, Chinese Academy of Agricultural Sciences (CAAS), Beijing-100193, China

${ }^{4}$ Animal Production Officer, Animal Production and Health Division, FAO, Italy

(Received: January 14, 2010) 
Bang. J. Anim. Sci. 2010, 39(1\&2)

For genetic improvement of any species, genetic characterization is the first and foremost priority. Genetic characterization can be done using isozymes, genomic DNA, mtDNA and chromosomes. Use of microsatellite marker is currently the marker of choice for a wide range of molecular genetic studies such as establishing genetic linkage maps (Kappes et al., 1997), analysis of mating system and population structures (Bruford and Wayne, 1993; Queller et al., 1993) and reconstruction of phylogenetic relationships among populations (Bowcock et al., 1994; Roy et al., 1994; Takezaki and Nei, 1996; MacHugh et al., 1997). Microsatellite markers has been used successfully for study of genetic diversity and relationship of goat breeds/populations by Yang et al. (1999), Luikart et al. (1999), Saitbekova (1999), Chenyambuga et al. (2004), Jim'enez-Gamero et al. (2006), Thilagam et al. (2006) and Dixit et al. (2010). Katsumata et al. (1984) studied isozymes for the characterization of Bangladeshi goat. But there is no report on characterization of Bangladeshi goats based on microsatellite markers. The present study was, therefore, done to find out the genetic variation and relation among different populations of goats in Bangladesh using microsatellite markers.

\section{Materials and Methods}

\section{Sample collection, DNA extraction and quantification}

All the goats of Bangladesh were divided into five populations based on geographical distribution and history of breeding and management systems. These were (i) BBW- Black Bengal goats in the western part of the country, (ii) BBC- Black Bengal goats in the central part of the country, (iii) BBH- Black Bengal goats in the hilly area of the country, (iv) JAMimported Indian goats consist of Jamnapari, Sirohi and Beetal, and (v) CRW- crossbred between JAM and Black Bengal goat. Forty samples were collected from each population. However 30 samples were collected from JAM. So a total of 190 samples were collected for five populations (Fig. 1). Samples were collected only from adult goats of subsistent farmers taking a ratio of 1:3 for male and female. Samples were collected avoiding related animals. Blood was collected in venoject tube, treated with anticoagulant and carried to Animal Genetics Laboratory of Bangladesh Agricultural University and preserved at $4^{0} \mathrm{C}$ until DNA extraction. DNA was extracted following a salting out protocol after IAEA (2004). The DNA samples were quantified in $0.8 \%$ agarose gel electrophoresis.

\section{Microsatellite polymorphism detection}

PCR amplification and genotyping work were done in ILRI laboratory, Nairobi. All of 190 DNA samples were amplified in PCR system (GeneAmp 9700 PCR machine) using 15 pairs of microsatellite primers selected from FAO recommendation. All the microsatellite markers were forwardly labeled with a capillary based dye: 6FAM (blue), PET (Red), VIC (Green) and NED (yellow) for the purpose of genotyping. The PCR condition has been presented in Table 1 . PCR was carried out in $10 \mu \mathrm{l}$ reaction mixture containing $4 \mathrm{ng} / \mu \mathrm{l}$ of template DNA, $4 \mathrm{ng} / \mu \mathrm{l}$ each primer, $125 \mu \mathrm{M} / \mu \mathrm{l} \mathrm{dNTPs}, 0.03 \mathrm{unit} / \mu \mathrm{l}$ of Tag polymerase and 1.5 to $2.0 \mathrm{mM} / \mu \mathrm{l}$ of $\mathrm{MgCl}_{2}$. 
Genetic variation in Bangladeshi goats

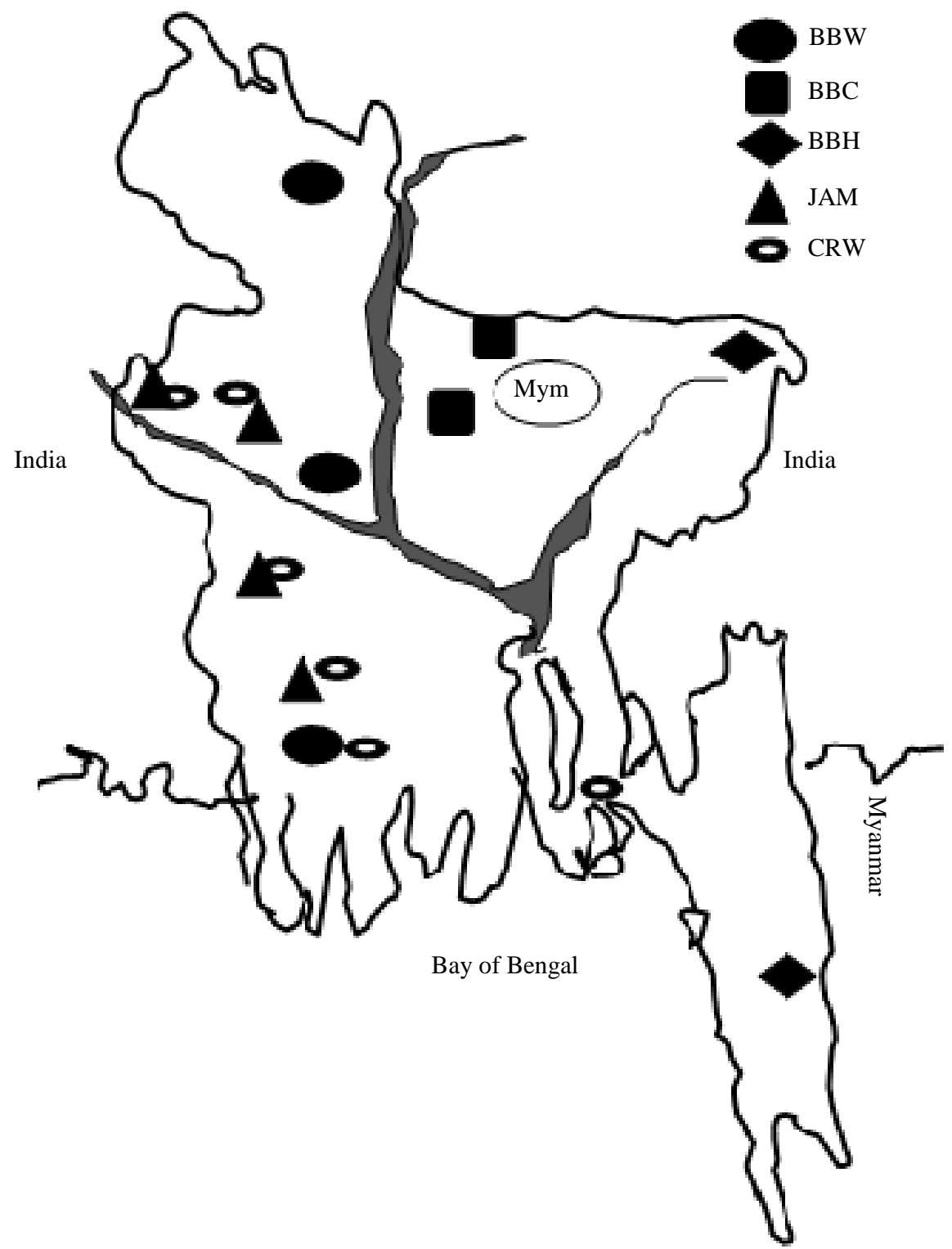

Fig. 1. Sites from where samples were collected. $B B W=$ Black Bengal in the western part; $B B C=$ Black Bengal in the central part; $\mathrm{BBH}=$ Black Bengal in the Hilly region; JAM = Imported Indian goat breed; CRW = Crossbred between Black Bengal and exotic goat breeds

PCR program used for amplification of all markers was: following an activation step of 5 min at $95^{\circ} \mathrm{C}$, the PCR mixture underwent 35 cycles of 30 seconds at $95^{\circ} \mathrm{C}$ (denaturation), annealing time of $1 \mathrm{~min}$ at $55^{\circ} \mathrm{C}$ and extension time of $1 \mathrm{~min}$ at $72^{\circ} \mathrm{C}$. The final extension time was $10 \mathrm{~min}$ at $72^{\circ} \mathrm{C}$. All PCR products were quantified by $2 \%$ agarose gel electrophoresis for checking the success of PCR amplification. The amplified DNA was genotyped by automated capillary DNA sequencer Genetic Analyzer (3730 of Applied 
Bang. J. Anim. Sci. 2010, 39(1\&2)

Biosystem, USA). The internal standard was prepared by adding $10 \mu \mathrm{l}$ of LIZ standard to 45 $\mu \mathrm{l}$ of HiDi formamide. A total of $1 \mu \mathrm{l}$ of diluted PCR product of each co-loading was transferred to individual wells with $9 \mu \mathrm{l}$ of standard/formamide mix and denatured for genotyping. The genotyping results were processed by the GeneMapper v 3.7 program which determined the allele sizes in each animal. A total of 181 samples including 36 from BBW, 39 from BBC, 40 from BBH, 38 from CRW and 28 from JAM were finally amplified and genotyped.

Table 1. PCR condition used for different markers

\begin{tabular}{|l|c|c|c|}
\hline Microsatellite markers & Size bp range & Annealing temp & Mg++ concentration \\
\hline ILSTS029 & $135-185$ & $55^{\circ} \mathrm{C}$ & $2.0 \mathrm{mM}$ \\
BMS1494 & $235-300$ & $55^{\circ} \mathrm{C}$ & $2.0 \mathrm{mM}$ \\
MAF035 & $90-130$ & $55^{\circ} \mathrm{C}$ & $2.0 \mathrm{mM}$ \\
SRCRSP3 & $95-135$ & $55^{\circ} \mathrm{C}$ & $2.0 \mathrm{mM}$ \\
BMS1818 & $240-310$ & $55^{\circ} \mathrm{C}$ & $2.0 \mathrm{mM}$ \\
OARFC20 & $80-130$ & $55^{\circ} \mathrm{C}$ & $2.0 \mathrm{mM}$ \\
ETH10 & $190-220$ & $53^{\circ} \mathrm{C}$ & $1.5 \mathrm{mM}$ \\
OARAE54 & $105-145$ & $55^{\circ} \mathrm{C}$ & $2.0 \mathrm{mM}$ \\
ILSTS005 & $160-230$ & $55^{\circ} \mathrm{C}$ & $2.0 \mathrm{mM}$ \\
SPS113 & $125-170$ & $58^{\circ} \mathrm{C}$ & $2.0 \mathrm{mM}$ \\
CSRD247 & $219-260$ & $58^{\circ} \mathrm{C}$ & $2.0 \mathrm{mM}$ \\
INRA0132 & $125-175$ & $58^{\circ} \mathrm{C}$ & $1.5 \mathrm{mM}$ \\
MCM527 & $155-195$ & $58^{\circ} \mathrm{C}$ & $2.0 \mathrm{mM}$ \\
MAF70 & $120-190$ & $65^{\circ} \mathrm{C}$ & $2.0 \mathrm{mM}$ \\
ILSTS011 & $250-300$ & $58^{\circ} \mathrm{C}$ & $2.0 \mathrm{mM}$ \\
\hline
\end{tabular}

\section{Statistical analysis}

The genotyped data were analyzed using Microsatellite Toolkit program (Minch, 1995) to calculate allele frequencies at each locus for each population, average number of alleles per population and heterozygosity values (expected and observed). Dispan program (Ota, 1993) was used to calculate $\mathrm{D}_{\mathrm{A}}$ genetic distances between the populations and a Neibour - Joining (NJ) phylogenetic tree was constructed using the PHYLIP 3.57c package (Felsentein, 1995).

\section{Results and Discussion}

\section{Distribution of alleles and heterozygosity within the populations}

All the goat populations showed polymorphism for microsatellite markers in the present study. The allele number per loci ranged from 2 to 12 in the five populations. A number of diagnostic alleles have been identified for different populations. The mean numbers of alleles along with heterozygosity values per population are presented in Table 2 . The mean numbers of alleles per population ranged from 5.23 (BBH) to 6.08 (CRW). The average observed 
heterozygosity values were medium in all populations ranging from 0.5049 to 0.5751 with the lowest in population BBC $(0.5049 \pm 0.0187)$ and the highest in population JAM $(0.5751$ \pm 0.0237 ). The genetic variation in the goat population of Bangladesh was first studied by Katsumata et al., 1984. They used isozymes as markers and studied on BBW, BBC and JAM populations of present study. They reported the existence of polymorphic loci in all these populations. However, the observed heterozygosity reported by them was lower ( 0.0337 to 0.0429 ) than the findings of present study (0.5049 to 0.5751$)$. The value of heterozygosity measured from isozymes is always lower than that measured from DNA. This is also evidence from the study of Nyamsamba, et al. (2003). The existence of polymorphism has also been reported in Indian and Chinese goats by a number of investigators (Ganai and Yadav, 2001; Kim, et al., 2002; Sultana et al., 2003; Ran et al., 2006; Anita and Yadav, 2007). They also reported medium level of heterozygosity in those populations.

Table 2. Mean number of alleles and heterozygosity for different populations

\begin{tabular}{|l|c|c|c|c|}
\hline Population & Loci type & No. alleles & Expected heterozygosity & Observed heterozygosity \\
\hline BBW & 15 & $5.69 \pm 2.32$ & $0.5411 \pm 0.0713$ & $0.5258 \pm 0.0231$ \\
BBC & 15 & $5.38 \pm 2.02$ & $0.5311 \pm 0.0734$ & $0.5049 \pm 0.0222$ \\
BBH & 15 & $5.23 \pm 2.28$ & $0.5473 \pm 0.0657$ & $0.5171 \pm 0.0219$ \\
CRW & 15 & $6.08 \pm 2.33$ & $0.5827 \pm 0.0600$ & $0.5708 \pm 0.0224$ \\
JAM & 15 & $5.77 \pm 2.35$ & $0.5925 \pm 0.0584$ & $0.5751 \pm 0.0262$ \\
\hline
\end{tabular}

\section{Genetic distances between the populations}

The $\mathrm{D}_{\mathrm{A}}$ genetic distances between different populations are presented in Table 3 . The standard genetic distance between the population pairs ranged from 0.0043 to 0.0498 . The lowest genetic distance (0.0043) was observed between CRW and JAM and the highest distance (0.0498) was observed between JAM and BBC. BBW had closer relationship to $\mathrm{CRW}$ than BBC and BBH. The genetic relationships among different populations are shown in the phylogenetic dendrogram (Fig. 2) constructed on the basis of $\mathrm{D}_{\mathrm{A}}$ distances and using Neibour- joining (NJ) method (Nei, 1978). In the phylogenetic dendrogram, goat populations of Bangladesh were divided into three groups, BBC and BBH clustered in the first group, BBW in the second group, and CRW and JAM in the third group separately. Such a. clustering of the goat breeds according to their geographical origin was also reported for Indian goat breeds by Thilagam et al. (2006) and Dixit et al. (2010), for Chinese goat breeds by Yang et al. (1999), for African goat breeds by Chenyambuga et al. (2004), and Swiss goat breeds by Saitbekova (1999).

From the history it is evident that CRW was crossed with imported goat breeds of India. Crossbreeding is more evidence in the western part of Bangladesh than central and eastern part or hilly region for the last 10 years as revealed from the history of goat mating system in the country. Because of the introgression of genes from exotic breeds, BBW possessed more exotic genes than BBC and BBH (Faruque and Khandoker, 2007). So CRW and BBW showed closed genetic relation and had a higher mean number of alleles (6.08 \pm 2.33 and 
Bang. J. Anim. Sci. 2010, 39(1\&2)

$5.69 \pm 2.32$, respectively) than $\mathrm{BBC}$ and $\mathrm{BBH}$. There was no introgression of genes from exotic breeds in BBH. Therefore, this population had the lowest mean number of alleles, lower heterozygosity value and highest genetic distance from JAM. Anita and Yadav (2007) also reported that Black Bengal and Jamnapari breed in India had larger genetic distance and they clustered separately in dendrogram. Therefore, BBH can be regarded as the most pure Black Bengal goat in Bangladesh.

Table 3. Genetic distance among different populations/breeds

\begin{tabular}{|l|c|c|c|c|c|}
\hline & BBW & BBC & BBH & CRW & JAM \\
\hline BBW & & & & \\
BBC & 0.0265 & & & & \\
BBH & 0.0179 & 0.0282 & & & \\
CRW & 0.0043 & 0.0415 & 0.0198 & & \\
JAM & 0.0189 & 0.0627 & 0.0498 & 0.0037 & \\
\hline
\end{tabular}

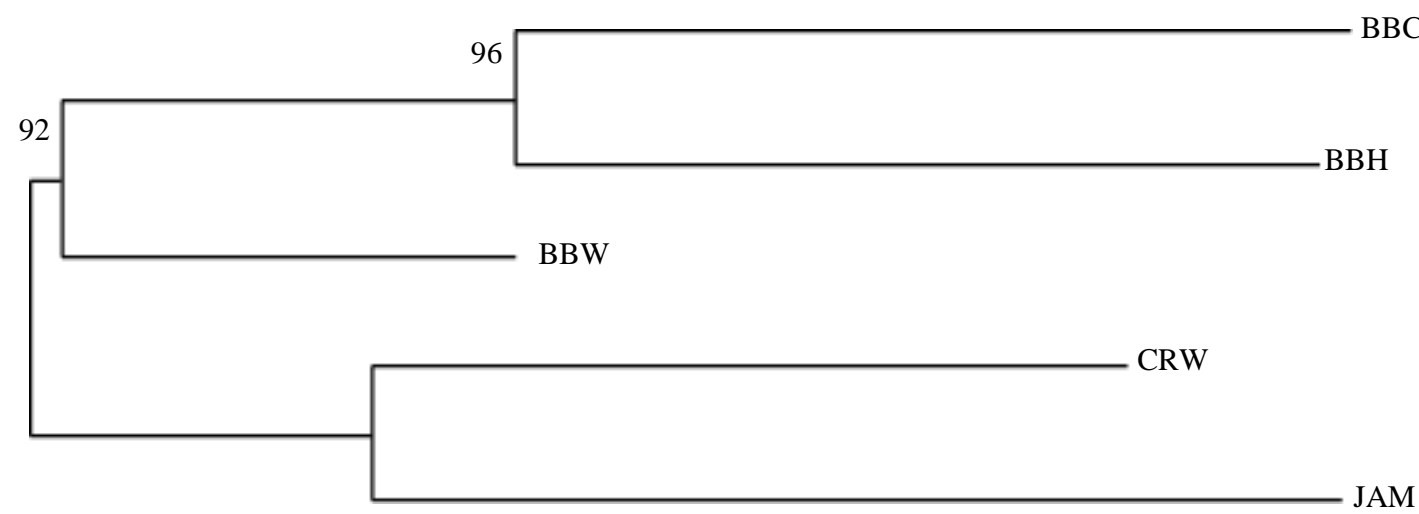

Fig. 2. Dendrogram for genetic relationship of five goat populations/breeds

BBW : Bangladesh north, BBC : Bangladesh central, BBH : Bangladesh Hilly, JAM : Exotic breeds,

CRW : Crossbred between Black Bengal and exotic breeds

\section{Conclusion}

It can be concluded that all the populations of goats in Bangladesh have high genetic diversity with medium heterozygosity. There is significant introgression of genes from exotic breeds in the populations of BBW than BBC and BBH. The results of the present study would be useful in planning breeding strategy for future genetic improvement program of goat in Bangladesh. 
Genetic variation in Bangladeshi goats

\section{Acknowledgement}

The authors thank to The International Atomic Energy Agency, International Livestock Research Institute and Bangladesh Agricultural University for their financial and technical support for this research work. Thanks also Officers and Field Staffs in the Department of Livestock Services for their assistance to collect the samples.

\section{Literature Cited}

Anita. Y. and Yadav, B. R. 2007. Genetic diversity among six breeds of Indian goat using RAPD markers. Biotech., 6(1): 57-60.

Bowcock, A. M. Linares, R. A., Tomfohrde, J., Minch, E., Kidd, J. R. and Carvalli-Sforza, L. L. 1994. High resolution of human evolutionary trees with polymorphic microsatellites. Nature., 368: 455-457.

Bruford, M. W. and Wayne, R. K. 1993. Microsatellites and their application to population genetic studies. Curr. Opin. Genet. Dev., 3(6): 939-43.

Chenyambuga, S. W., Hanotte, O., Hirbo, J., WattS, P. C., Kemp, S. J., Kifaro, G. C., Gwakisa, P. S. P., Petersen, H. and Rege, J. E. O. 2004. Genetic Characterization of Indigenous Goats of Subsaharan Africa Using Microsatellite DNA Markers. Asian-Aust. J. Anim. Sci., 17( 4): 445-452.

Dixit, S. P., Verma, N. K., Aggarwal, R. A. K., Vyas, M. K., Rana, J., Sharma, A., Tyagi, P., Arya, P. and Ulmek, B. R. 2010. Genetic diversity and relationships among southern Indian goat breeds based on microsatellite markers. Small Rum. Res., 91(2 ): 153-159.

DLS. 2007. Livestock statistics of Bangladesh. Department of Livestock Services, Dhaka.

FAOSTAT. 2009. http://faostat.fao.org

Faruque, M. O. and Khandoker, M. A. M. Y. 2007. Recent advance in goat genotyping in Bangladesh. In proceedings recent advance in livestock genotyping in Bangladesh, BARC, Dhaka held on 10 May, 2007. pp. 28-39.

Felsenstein, J. 1995. PLYLIP phylogeny soft were version 3.7c. Department of Genetics, University of Washington, Seattle, Washington.

Ganai, N. A. and Yadav, B. R. 2001. Genetic variation within and among three Indian breeds of goat using heterogonous micro satellite markers. Anim. Biotechnol., 12(2): 121-136.

IAEA. 2004. Hand book on FAO/IAEA inter-regional training course on molecular methods in livestock genetics and breeding. International Atomic Energy Agency Laboratory, Seibergdorf, Austria, June 14-25, 2004.

Jim’enez-Gamero, I., Dorado, G., Mũnoz-Serrano, A., Analla, M. And Alonso-Moraga, A. 2006. DNA micro satellites to ascertain pedigree-recorded information in a selecting nucleus of Murciano-Granadina dairy goats. Small Rum. Res., 65(3): 266-273.

Kappes S. M., Keele J. W., Stone R.T. 1997. A second generation linkage map of the bovine genome. Gen. Res., 7: 397-400. 
Bang. J. Anim. Sci. 2010, 39(1\&2)

Katsumata, M., Amano, T., Nozawa, K., Tsunoda, K., Namikawa, T., Tsubota, Y., Hasnath, M. A., Mostafa, K. G., and Faruque, M. O. 1984. Body measurements and blood protein variation of the native goats in Bangladesh. In: Genetics Studies on Breed Differentiation of Native goats in Bangladesh (Edi. T. Amano). Tokyo Univ. Agric. pp. 101-114.

Kim, K. S., Yeo, J. S., Lee, J. W., Kim, J. W. and Choi, C. B. 2002. Genetic diversity of goats from Korea and China using microsatellite analysis. AJAS, 15(4): 461-465.

Luikart,G., Biju-Duval, M.P., Ertugrul, O., Zagdsuren, Y., Maudet, C. and Taber. P. 1999. Power of 22 microsatellite markers in fluorescent multiplexes for parentage testing in goats (Capra hircus). Anim. Gen., 30(6): 431-438.

MacHugh, D. E., Shriver, M. D., Loftus, R. T., Cunningham, E. P., and Bredley, D. G .1997 Microsatillite DNA variation and the evolution, domestication and phylogeography of taurene and zebu cattle (Bos tarus and Bos indicus). Gen., 146: 1021-86.

Minch, E., Ruiz-Linares, A. and Goldstein, D. B. 1995. Microsat (version 1.5d): a program for calculating statistics on micro satellite allele data.

Nei, M. 1978. Estimation of average heterozygosity and genetic distance from a small number of individuals. Gen., 89: 583-590.

Nyamsamba, D., Nomura,K., Nozawa, K., Yokohama, M, Zagdsuren, K. Y. and Amano, T. 2003. Genetic relationship among Mongolian native goat populations estimated by blood protein polymorphism. Small Rum. Res., 47(3): 171-181.

Ota, T.1993 .DISPAN: Genetic distance and phylogenetic Analysis. Pennsylvania state university, university park, PA.

Queller, D. C., Strassmann, J. E. and Hughes, C. R. 1993. Microsatellites and Kinship. Trends in Ecology and Evolution., 8: 285-288.

Ran, D., Ma, Y. H. and Guan, W. J. 2006. Initial analysis of genetic diversity of Chinese four cashmere goats breeds. Anim. Biot. Bull., 10(1): 499-502.

Roy, M. S., Geffen, E., Smith, D., Ostrander, E.A. and Wayne, R. K.1994. Patterns of differentiation and hybridization in North American Wolflike canids revealed by analysis of microsatellite loci. Mol. Biol. Envol., 11: 553-70.

Saitbekova, N., Gaillard, C., Obexer-Ruff, G. and Dolf. G.1999. Genetic diversity in Swiss goat breeds based on microsatellite analysis. Anim. Gen., 34(1): 36-41.

Sultana, S., Mannen, H. and Tsuji, S. 2003. Mitochondrial DNA diversity of Pakistani goats. Anim. Gen., 34(6): 417-421.

Takezaki, N. and Nei, M.1996. Genetic distances and reconstruction of phylogenetic trees from microsatellite DNA. Gen., 144: 389-399.

Thilagam, K., Ramamoorthi, J., Sivaselvam, S. N., Karthickeyan, S. M. K. and Thangaraju, P.2006. Kanniadu goats of Tamilnadu, India: genetic characterisation through microsatellite markers. Livest. Res. Rural Develop., 18(10) 2006, 149-150.

Yang, l., Zhao, S H., Li, K., Peng, Z. Z. and Montgomery G. W. 1999. Determination of genetic relationships among five indigenous Chinese goat breeds with six microsatellite markers. Anim. Gen., 30(6): 452- 455. 